\title{
DHA content in milk and biohydrogenation pathway in rumen: A review
}

\author{
Guoxin Huang ${ }^{\text {Equal first author, } 1,2}$, Yangdong Zhang ${ }^{\text {Equal first author, } 1}{ }^{1}$, Qingbiao Xu ${ }^{3}$, Nan Zheng ${ }^{1}$, Shengguo Zhao ${ }^{1}$, Kaizhen Liu \\ ${ }^{1}$, Xueyin $\mathbf{Q u}{ }^{4}$, Jing Yu ${ }^{4}$, Jiaqi Wang ${ }^{\text {Corresp. } 1}$ \\ ${ }^{1}$ Chinese Academy of Agricultural Sciences, State Key Laboratory of Animal Nutrition, Institute of Animal Science, Beijing, China \\ 2 Northeast Agricultural University, College of Animal Sciences and Technology, Harbin, China \\ 3 Huazhong Agricultural University, College of Animal Sciences and Technology, Wuhan, China \\ 4 Tianjin Mengde Groups Co., Ltd, Tianjin, China \\ Corresponding Author: Jiaqi Wang \\ Email address: wangjiaqi@caas.cn
}

Docosahexaenoic acid (DHA) is an essential human nutrient that may promote neural health and development. DHA occurs naturally in milk in concentrations that are influenced by many factors, including the dietary intake of the cow and the rumen microbiome. We reviewed the literature of milk DHA content and the biohydrogenation pathway in rumen of dairy cows aim to enhance the DHA content. DHA in milk is mainly derived from two sources: $\alpha$-linolenic acid (ALA) occurring in the liver and consumed as part of the diet, and overall dietary intake. Rumen biohydrogenation, the lymphatic system, and blood circulation influence the movement of dietary intake of DHA into the milk supply. Rumen biohydrogenation reduces DHA in ruminal environmental and limits DHA incorporation into milk. The fat-1 gene may increase DHA uptake into the body but this lacks experimental confirmation. Additional studies are needed to define the mechanisms by which different dietary sources of DHA are associated with variations of DHA in milk, the pathway of DHA biohydrogenation in the rumen, and the function of the fat-1gene on DHA supply in dairy cows. 


\section{DHA Content in Milk and Biohydrogenation Pathway in}

\section{Rumen: A Review}

3

4

5 Guoxin Huang ${ }^{1,2}+$, Yangdong Zhang ${ }^{1}+$, Qingbiao $\mathrm{Xu}^{3}$, Nan Zheng ${ }^{1}$, Shengguo Zhao ${ }^{1}$, Kaizhen Liu ${ }^{1}$, Xueyin

$6 \mathrm{Qu}^{4}$, Jing $\mathrm{Yu}^{4}$, Jiaqi Wang ${ }^{1 *}$

7

$8 \quad$ tGuoxin Huang and Yangdong Zhang contributed equally to this work.

$9{ }^{1}$ State Key Laboratory of Animal Nutrition, Institute of Animal Science, Chinese Academy of Agricultural

10 Sciences, No. 2 Yuanmingyuan West Road, Haidian District, Beijing 100193, China;

$11{ }^{2}$ College of Animal Sciences and Technology, Northeast Agricultural University, Harbin, 150030, China;

$12{ }^{3}$ College of Animal Sciences and Technology, Huazhong Agricultural University, Wuhan, 430070, China;

$13{ }^{4}$ Tianjin Mengde Groups Co., Ltd. Tianjin, 300400, China.

14

15 Corresponding author:

16 Jiaqi Wang (J.Q. Wang)

17
Address: Institute of Animal Science, Chinese Academy of Agricultural Sciences, Haidian District, Beijing, PR China.

Tel: +8610 62816069; fax: +861062897587.

E-mail: wangjiaqi@caas.cn (J.Q. Wang). 


\section{ABSTRACT}

Docosahexaenoic acid (DHA) is an essential human nutrient that may promote neural health and development. DHA occurs naturally in milk in concentrations that are influenced by many factors, including the dietary intake of the cow and the rumen microbiome. We reviewed the literature of milk DHA content and the biohydrogenation pathway in rumen of dairy cows aim to enhance the DHA content. DHA in milk is mainly derived from two sources: $\alpha$-linolenic acid (ALA) occurring in the liver and consumed as part of the diet, and overall dietary intake. Rumen biohydrogenation, the lymphatic system, and blood circulation influence the movement of dietary intake of DHA into the milk supply. Rumen biohydrogenation reduces DHA in ruminal environmental and limits DHA incorporation into milk. The fat-1 gene may increase DHA uptake into the body but this lacks experimental confirmation. Additional studies are needed to define the mechanisms by which different dietary sources of DHA are associated with variations of DHA in milk, the pathway of DHA biohydrogenation in the rumen, and the function of the fat-1gene on DHA supply in dairy cows.

Keywords: $\alpha$-linolenic acid, biohydrogenation, dairy cows, Docosahexaenoic acid, fat-1 gene, ruminal microorganism. 


\section{INTRODUCTION}

Some researchers reported that milk fat could increase triglycerides in blood. However, many researches showed milk fat had no adverse effects on the concentrations of fasting blood lipids, glucose, and insulin (Benatar, Sidhu \& Stewart, 2013; Engel Elhauge \& Tholstrup, 2017). And even some study showed benefit for blood pressure supplement with milk fat (Rietsema et al., 2019). Substances found in enriched milk, including medium and odd chain SFA (saturated fatty acid), globular phospholipids, unsaturated fatty acids, branched-chain fatty acids, natural trans fatty acids, vitamins $\mathrm{K} 1$ and $\mathrm{K} 2$, and calcium, have been found to have positive health effects (Mozaffarian \& Wu, 2018). Among them, conjugated linoleic acid (CLA), which is peculiarly originated from the rumen (Jaglan, 2019), and omega-3 polyunsaturated fatty acids (n-3 PUFA) have been found to show health benefits to humans (Swanson, Block \& Mousa, 2012).

Docosahexaenoic acid (DHA, C22:6n-3) is an n-3 PUFA found in the mammalian central nervous system (Gázquez, 2017), making up 10\% to 15\% of the total cerebral fatty acids (about $10 \mu \mathrm{mol} / \mathrm{g}$ brain). Some bacteria and lower eukaryotes can produce DHA de novo via a polyketide synthase pathway (Kabeya et al., 2018) but humans lack the key fat desaturase enzyme for synthesizing DHA (especially $\Delta 12$ and $\Delta 13 / \mathrm{n}-3$ desaturase). 2008 FAO/WHO (2008) recommended a daily intake of DHA+EPA of $300 \mathrm{mg}$ for lactating women, recent studies shown a daily intake of $100 \mathrm{mg}$ DHA for infants and $250 \mathrm{mg}$ /day for adolescents DHA+ Eicosapentaenoic acid (EPA, C20:5n-3) (Saini and Keum 2018; Saini et al. (2018). The American Heart Association recommends an intake of 2-4 g/day of DHA+EPA for hypertriglyceridemia patients (Michael et al., 2011). Gebauer et al., (2006) recommended an intake of approximately $500 \mathrm{mg} / \mathrm{d}$ of EPA+DHA to reduce the risk of cardiovascular disease. However, most populations only get approximately $100 \mathrm{mg}$ of DHA+EPA per day, which is much lower than the recommendations (Afshin et al., 2019).

The human body can synthesize DHA in extremely limited amounts using $\alpha$-linolenic acid (ALA, C18:3n-3) (Plourde \&amp; Cunnane, 2007), and only approximately 0-4\% of dietary ALA may be converted to DHA (Burdge \&amp; Wootton, 2002), so DHA needs to be supplemented (Hashimoto et al., 2017).

Milk is a possible dietary source of DHA, dietary source of DHA, but its concentration is particularly low (Bai et al., 2018; Ishaq \& Nawaz, 2018; Shingfield, Bonnet \& Scollan, 2013). The DHA content of milk is influenced by the rumen microbiota, endogenous synthesis, and dietary intakes of DHA by dairy cows. The rumen biohydrogen content limits the efficient dietary incorporation of DHA into milk and the pathway of DHA hydrogen in the rumen is still unclear. Fat-1 gene was also used to increase DHA in milk (Wu et al., 2012), but researches is limited. We mainly analyzed the literature and defined factors affecting the conversion of dietary DHA into milk and explored strategies to increase the DHA content in milk.

\section{Methodology}

The scholarly articles in this review were obtained from web of knowledge, google scholar Baidu scholar and subject-specific professional websites, the date from 1999-2019. The keywords "dairy cow", 
"dairy cattle", "rumen", "bacteria", "biohydrogenation" "DHA", "microalgae" and "fish oil" were used in the search. All of the articles included in this review were peer-reviewed. The article chose in this paper should show the relation between DHA with dairy cow bacteria or rumen biohydrogenation. The qualitative and quantitative articles were reviewed in this paper. The qualitative articles provide insights into problems by helping to understand the reason and opinions. The quantitative articles use measurable data to express facts and discover research patterns.

\section{SOURCES OF DHA IN MILK}

DHA in milk comes from three major sources: those synthesized from endogenous ALA, those synthesized by the microorganisms in the rumen and intestines of cows, and those converted from the diet.

\section{Metabolic Conversion of ALA to DHA}

DHA can be synthesized from ALA through metabolic pathways in the liver (Figure 1) (Kabeya et al., 2018; Kim et al., 2014). The process occurs in the endoplasmic reticulum and peroxisome, which are organelles. ALA is desaturated to stearidonic acid in the endoplasmic reticulum (C18:4n-3) catalyzed in a rate-limiting reaction by $\Delta 6$ desaturase and then converted to tetracosahexaenoic acid (C24:6n-3). Tetracosahexaenoic acid is then transferred into peroxisome where it undergoes $\beta$-oxidation to form DHA. The reaction sequence for converting ALA to eicosatetraenoic acid (C20:4n-3) is as follows: ALA $\rightarrow$ eicosatrienoic acid (C20:3n-3) $\rightarrow$ C20:4n-3 (Kabeya et al., 2018). $\Delta 6$ and $\Delta 5$ desaturases are the key enzymes in the metabolic pathways (Missotten et al., 2009) and the activity of these two desaturate enzymes can determine the amount of DHA synthesized. For example, the expressions of $\Delta 6$ and $\Delta 5$ desaturase in human subjects are positively correlated with SFA and PUFA but negatively correlated with linoleic acid (LA) and ALA in foods (Xiang et al., 2006). Omega-6 polyunsaturated fatty acids (n-6 PUFA) are essential in human and animal diets (Saini \& Keum, 2018). Changing the ratio of n-3:n-6 PUFA in the diet can influence the expression of $\Delta 6$ desaturase enzyme in rats (Missotten et al., 2009; Neuringer, Anderson \& Connor, 1988). Missotten et al., (2009) added fish oil and linseed oil to pig diets and determined the expressions of $\Delta 6$ and $\Delta 5$ desaturase in the liver, subcutaneous fat, and the longissimus dorsi muscle. The addition of fish oil increased the expression of $\Delta 5$ desaturase only in the longissimus dorsi muscle, but not in the liver or subcutaneous fat; the addition of linseed oil had no effect on the expression of $\Delta 5$ desaturase in all three tissues; the expression of $\Delta 6$ desaturase in all three tissues was not affected by either type of oil (Missotten et al., 2009). Studies in rats have shown that protein (Narce et al., 1988) and micromineral (Johnson et al., 1989) depletion in the diet reduced the activity of the $\Delta 6$ desaturase enzyme. There have been no reports on the effect of dietary fat on the expression of $\Delta 6$ and $\Delta 5$ desaturases in cows.

\section{Synthesis of DHA by rumen microorganisms}

Microorganisms, including microbes in the ocean and environment, are able to synthesize DHA de novo via a polyketide synthase pathway (Kabeya et al., 2018; Dongming, Jackson, \& Quinn, 2015; Xue et al., 2013). 
Diverse and interdependent populations of bacteria, protozoa, and fungi inhabit the rumen of dairy cattle (Russell \& Rychlik, 2001) but no studies have been conducted to date that show the relationship between rumen microbes and DHA metabolism. Some articles have indicated that microbes in the rumen may synthesize DHA independently. For example, Bianchi et al. (2014) found that Cellulophaga can produce DHA. Cellulophaga belongs to phylum Bacteroidetes which is the most abundant phylum in the rumen of older dairy cows (Jami et al., 2013), and infers that there may be a kind of microbe (belong to phylum Bacteroidetes) in the rumen that can produce DHA. Yarrowia lipolytica is a yeast widely distributed in the natural environment that can also produce DHA (Dongming, Jackson \&amp; Quinn, 2015; Damude et al., 2006; Gong et al., 2014), however, it is not clear if yeast living in the rumen can produce DHA (Prakasan et al., 2013). In an in vivo experiment with dairy cows, the animals were fed diets containing linseeds or no linseeds, and no DHA at all, but DHA was subsequently found in the duodenal chyme $(0.07 \mathrm{~g} / \mathrm{d}$ and $0.08 \mathrm{~g} / \mathrm{d}$, respectively) (Shingfield K J, Lee M R F , Humphries D J , et al. Effect of linseed oil and fish oil alone or as an equal mixture on ruminal fatty acid metabolism in growing steers fed maize silage-based diets[J]. Journal of Animal Science, 2011, 89(11):3728-41) (Kairenius, Toivonen \& Shingfield, 2011). The DHA in the chyme came from the rumen and originated from synthesis by rumen microorganisms or from the blood circulation into salivary secretions.

Additional research may need to focus on the identification of DHA-producing bacteria in the rumen. Increasing the content of DHA-producing bacteria present may increase DHA synthesis in the rumen, which results in more DHA in milk. In addition, there may exist interrelationships in DHA synthesis between microbial species with a functional network (Moraïs \& Mizrahi, 2019), which should be explored.

\section{Dietary DHA}

An increase in dietary DHA can significantly increase the bodily content of DHA and the subsequent milk content of DHA (Scollan et al., 2001a; Vahmani, Fredeen \& Glover, 2013). Currently, the major dietary DHA sources for cows are fish oil and microalgae products.

\section{Fish oil}

Fish oils contain a variety of n-3 PUFA, of which EPA and DHA are the most abundant (Mahla et al., 2017).

Studies have been conducted on supplementing the diets of dairy cattle with fish oil (Table 1) and most studies indicate that this practice could reduce milk fat. The study conducted by Pirondini et al. (2015) showed no negative effects of fish oil ( $0.8 \%$ dry matter) on milk fat when cattle were provided a low starch diet. The type of diet fed, including the percentage of forage (Shingfield et al., 2003) and type of forage (Chilliard, Ferlay \& Doreau, 2001), plays an important role in milk fat concentrations.

The supplementation of fish oil alone or fish oil combined with other oils (such as extruded soybean, canola oil) all resulted in improved DHA concentrations in milk (Vahmani, Fredeen \& Glover, 2013; AbuGhazaleh et al., 2002; Ramaswamy et al., 2001; Vafa et al., 2012; Whitlock et al., 2002). Kairenius et al. (2015), supplemented with fish oil at doses of 75, 150 and 300g/day (around 0.4, 0.8 and 1.88\% diet) which increased the DHA concentration in milk $(0.03,0.05$ and $0.10 \mathrm{~g} / 100 \mathrm{~g}$ total milk fatty acid or $0.22,0.39$ and $0.67 \mathrm{~g} /$ day in milk). Other studies have shown a positive correlation for DHA content between dietary intake and milk 
142

143

144

145

146

147

148

149

150

151

152

153

154

155

156

157

158

159

160

161

162

163

164

165

166

167

168

169

170

171

172

173

174

175

176

177

concentrations (Lacasse et al., 2002). However, increased supplementation had no constant linear relationship between dietary DHA intakes and DHA concentrations in milk. Donovan et al. (2000) showed that supplementation with fish oil at 0,1 and $2 \%$ of total diet increased DHA concentrations in milk, but that the concentration decreased with $3 \%$ of total diet fish oil supplementation. Kairenius et al. (2015) reported no difference between the control group and $75 \mathrm{~g}$ /day supplementation group for DHA concentrations ( 0.03 to 0.03 $\mathrm{g} / 100 \mathrm{~g}$ total milk fatty acid or 0.22 to $0.22 \mathrm{~g} /$ day in milk). There may be a liner relationship between fish oil supplementation and milk DHA within certain range, which may be between $0.4 \%$ to $3 \%$.

The DHA content of milk is also affected by the host's metabolism and the biohydrogenation pathway in the rumen. In theory, minimizing the effects of rumen biohydrogenation in the rumen could increase the DHA content of milk (Casta Eda-Gutiérrez et al., 2007). However, Lacasse et al. (2002) reported that supplementation with fish oil or rumen-protected fish oil at the same doses in the diet made no difference in the DHA concentration of milk. This effect may be due to the reduced digestibility of DHA in rumen-protected fish oil. Dietary supplementation of fish oil can increase the DHA content of milk, but the effect of DHA intake is affected by many factors that need to be quantitatively defined.

\section{Microalgae}

Microalgae are microscopic photosynthetic organisms found in marine and fresh waters that are used as an animal feed (Priyadarshani \& Rath, 2012). Microalgae are a good source of protein, carbohydrates, and long chain PUFA, some of which are rich in DHA (Ryckebosch et al., 2014). Microalgae have been shown to improve the DHA content in milk when used as an additive to dairy cattle feed (Altomonte et al., 2018). The effects of microalgae supplementation on the fatty acid profile of milk are summarized in Table 2.

Supplementation with microalgae has been shown to improve the DHA concentration of milk with a negative effect on the overall fat content of milk. Microalgae supplementation has a liner relationship with the DHA content of milk (Altomonte et al., 2018; Boeckaert et al., 2008; Fougère, Delavaud \& Bernard, 2018; Póti et al., 2015) and fish oil has been shown to have the same effect. Three microalgae feeding styles were utilized (microalgae, rumen protect microalgae, and microalgae oil) and each produced unique results. The feeding of rumen-protected microalgae can improve the concentration of milk DHA markedly, compared to feeding microalgae alone (Franklin et al., 1999). Rumen-protected microalgae can reduce the biohydrogenation of DHA in the rumen. Stamey, Shepherd, Veth \& Corl (2012) supplemented with $150 \mathrm{~g} /$ day of microalgae and $194 \mathrm{~g} /$ day of microalgae oil, respectively, and found that the microalgae oil supplementation produced a lower milk fat content, DHA concentration and efficient transport of dietary DHA into milk compared with supplementation of microalgae. The DHA in microalgae oil is able to be biohydrogenated in the rumen more easily than microalgae, although DHA is chosen as a source of dietary DHA more often. Moate et al. (2013) reported that there is an exact linear relationship between microalgae intake and the DHA content of milk. However, no experiments have revealed the range in which microalgae supplementation has a linear relationship with the DHA concentration of milk.

An increased concentration of DHA in milk depends on the DHA content in dietary microalgae and is 
dependent on the species of microalgae and its processing methods. There are many kinds of microalgae that can be used in animal diets with substantially different levels of DHA (Madeira et al., 2017) that can be influenced by the way they are processed. Protecting microalgae from rumen degradation can preserve approximately $45 \%$ of the DHA content versus un-protected microalgae (Stamey et al., 2012).

\section{Transport ratio of DHA in milk}

The efficiency of DHA incorporation from the feed into milk was low, as showed in table 3. The incorporation efficiency of DHA can be calculated as the ratio of milk DHA content to dietary DHA intake. Fish oil supplementation increased the DHA content in milk by approximately $6.86 \%$ (range from $1.35 \%$ to $14.4 \%$ ), while microalgae supplementation increased it approximately $7.08 \%$ (range from $1.09 \%$ to $14.0 \%$ ). The efficiency can be influenced by many factors.

\section{TRANSPORTATION OF DIETARY DHA INTO MILK}

Figure 2 shows how dietary DHA is moved through the body into the milk. The majority of dietary DHA is hydrogenated in the rumen, with $60-98 \%$ of DHA transformed in the rumen to the corresponding geometric isomers via cis-trans isomerization of double bonds in DHA (NRC, 2001; Scollanet al. 2001; Kim et al. 2008; Kim et al. 2008; Shingfield et al 2011; Shingfield et al 2012; Kairenius et al 2018 ). Intact DHA (or by-pass) flows into the small intestine where approximately $70-100 \%$ is absorbed (Doreau et al. 1994; Wachira et al. 2000; NRC 2001; Scollanet al. 2001; Mattos et al. 2004). It is then absorbed via the lymphatic system into the blood circulation system (Doreau \& Ferlay, 1994; Scollan et al., 2001b; USA, 2001; Wachira et al., 2000) and is transported via the blood into various tissues and organs of the body, including the brain (Al-Ghannami, AlAdawi \& Ghebremeskel, 2019), bones (Saini \& Keum, 2018), and the reproductive system (Gholami et al., 2010 ), where it is used for tissue repair or energy supply via the $\beta$-oxidative pathway. Only $13-25 \%$ of DHA absorbed from the small intestine is transported into milk through the mammary gland cells (Shingfield, Bonnet \& Scollan, 2013).

The biohydrogenation of DHA in the rumen increases the amount of DHA lost by the body (Figure 2) (Kairenius et al., 2018; Kim et al., 2008; Mattos et al., 2004; Scollan et al., 2001; Shingfield et al., 2003; Shingfield et al., 2012; Shingfield et al., 2011; USA, 2001; Wachira et al., 2000). Therefore, reducing the biohydrogenation of DHA in the rumen is important for improving the DHA concentration of milk.

\section{Ruminal Biohydrogenation}

Ruminal biohydrogenation limits the transportation of dietary DHA into milk and is influenced by rumen microbes. Rumen microorganisms include bacteria, protozoa, and fungi. Bacteria play an important role in the biohydrogenation process (Louren, Ramos-Morales, and Wallace, 2010). DHA has two dietary forms: free fatty acids and triacylglycerols. Triacylglycerols must be converted into free fatty acids and then must undergo biohydrogenation by the rumen microbes. Thus, two kinds of microorganisms exist with lipolytic effects and biohydrogenation properties.

The lipolytic effect of triacylglycerols mainly depended on the lipase, Anaerovibrio lipolyticus, which is 
213

214

215

216

217

218

219

220

221

222

223

224

a prominent ruminal lipase-producing bacterium (Hungate, 1966). Three putative lipase genes were identified from the draft genome of Anaerovibrio lipolyticus (alipA, alipB, alipC) (Privé et al., 2013) and had greater hydrolytic activity against caprylate (C8:0), laurate (C12:0), and myristate (C14:0). Butyrivibrio fibrisolvens, Propionibacterium (Edwards et al., 2012) Clostridium, Propionibacterium, Staphylococcus (Edwards et al., 2013), and Pseudomonas aeruginosa (Priji et al., 2017) are among the bacteria that have the ability to decompose triacylglycerols. Sargolzehi et al. (2015) showed that pyridostigmine bromide could decrease the lipase activity and the immunization against lipase may also inhibit the decomposition of triacylglycerols, just like the immunization against rumen urease inhibits ureolysis in the rumen (Zhao et al., 2015).

Butyrivibrio sp. is a genus of an important microbe that hydrogenates PUFA in the rumen; it includes Butyrivibrio fibrisolvens (B. fibrisolvens), and Butyrivibrio proteoclasticus (B. proteoclasticus). B. fibrisolvens can produce isomerase and change the PUFA structure (for example, converting LA into CLA) (Kepler et al., 1966). Trans-11 vaccenic acid (C18:1), converted from LA, can be hydrogenated to stearic acid (C18:0) by $B$. proteoclasticus (Jenkins et al., 2007). However, some studies show that B. fibrisolvens failed to successfully induce DHA hydrogenation in the rumen (Jeyanathan, et al., 2016; Maia et al., 2007). B. proteoclasticus could hydrogenate DHA (Jeyanathan et al., 2016) in vitro in a growth medium containing autoclaved ruminal fluid. Bacterial species, such as Acetobacter (Bainbridge, et al., 2016) and Bacillus (Petri et al., 2014), but not Butyrivibrio sp., can affect DHA biohydrogenation. However, an experiment by Sakurama et al. (2014) reported that no bacteria (100 strains of anaerobic bacteria were used, Acetobacter was included) metabolized DHA. Dietary PUFA has been shown to strongly influence microbial profiles in the rumen. Many studies have shown that DHA intake in a reduction of B. fibrisolvens in the rumen in a dose-dependent manner (Shingfield et al., 2012; Maia et al., 2010; Shinji et al., 2009). Abughazaleh \& Ishlak (2014) reported that supplement with DHA could reduce the abundance of $B$. proteoclasticus, but other experiments have shown no effect. Shingfield et al. (2012) proposed that DHA and other unsaturated fatty acids could lengthen the bacteria's lag phase. It is well known that rumen bacteria release hydrogens and secrete isomerases, which may hydrogenate the double bonds in unsaturated fatty acids. The biohydrogenase in the rumen is a major factor regulating the biohydrogenation of PUFA. Further studies should focus on the relationship between rumen microbes, DHA, and biohydrogenase.

The formation of DHA can also be influenced by the intake of LA. LA can be converted into highly unsaturated fatty acids (HUFA) in vivo. LA and ALA share the same family of enzymes in the formation of HUFA (Fleming \& Kris-Etherton, 2014), and compete with one another for enzyme uptake (Gibson, Muhlhausler \& Makrides, 2015). Increasing the intake of LA may reduce the formation of DHA from ALA. A study showed that high LA diet could reduce the content of DHA in milk (Aprianita et al. 2014). However, DHA synthesis by ALA in tissues is very low and yet not reported in dairy cows. Ruminal biohydrogenation process is well-studied and understood. The content of unsaturated fatty acids in the diet can influence the biohydrogenation of DHA in the rumen, to various effects. In an in vitro study, Chow et al. (2004) found that adding LA and ALA could reduce the biohydrogenation of DHA, which was confirmed in an in vitro experiment (Wasowska et al., 2006). Shingfield et al. (2011) found that dietary supplementation of both fish oil and linseed 
249

250

251

252

253

254

255

256

257

258

259

260

261

262

263

264

265

266

267

268

269

270

271

272

273

274

275

276

277

278

279

280

281

282

283

oil at a ratio of 1:1 reduced the hydrogenation of DHA, but increased the hydrogenation of ALA in the rumen. However, Kairenius et al. (2018) reported that dietary addition of linseed oil or sunflower seed oil could promote the biohydrogenation of DHA, EPA, and ALA compared with fish oil alone. We determined that biohydrogenase is not fatty-acid specific and competition exists among unsaturated fatty acids. Short-chain unsaturated fatty acids may tend to be biohydrogenated more readily than long-chain PUFA. Therefore, understanding the mechanisms of biohydrogenation for unsaturated fatty acids and the interactions among these fatty acids in the rumen will help develop dietary strategies to reduce DHA biohydrogenation.

\section{Biohydrogenation Pathways of DHA in Rumen}

Studies on the DHA biohydrogenation pathway in the rumen are limited. In 2007, Jenkins et al. (2007) speculated that the first step in the process of DHA biohydrogenation is to convert DHA to a C22:6 isomer that is then hydrogenated to C22:5 fatty acid. However, Kairenius, Toivonen \& Shingfield (2011) showed that the C22:6 isomer was not detectable in the DHA hydrogenation process, likely due to its short lifetime or the limitation of the analytic method (Escobar et al., 2016). Aldai et al. (2018) investigated the biohydrogenation process of DHA in in vitro fermentation using sheep rumen fluid as the inoculator, and determined the metabolites of DHA at 0 , 1-, 2-, 3-, and 6- hours after fermentation. They found that DHA was initially transformed into mono trans methylene interrupted DHA and monoconjugated DHA. Nevertheless, the DHA hydrogenation process started from the isomer formation.

Jeyanathan, et al. (2016) used in vitro anaerobic fermentation with a single strain of Butyrivibrio proteoclasticus P18 to explore the biohydrogenation process of DHA during fermentation and showed the product in the DHA biohydrogenation pathway. This experiment showed that 12 kinds of DHA intermediates (C22:5, C22:4, C22:3 and C22:2 isomers) were transformed in 48h. Toral et al. (2018) found that Docosapentaenoic acid may be a major DHA intermediate product. DHA intermediates and the hydrogenation pathway in the rumen are illustrated in Figure 3.

The literature is lacking for enzymes that may regulate the DHA hydrogenation pathway in the rumen. According to a report by Toral et al. (2018), some enzymes may exist relating to hydrogenation, isomerization, and migration in the EPA hydrogenation pathway. However, the specific enzymes have not been identified yet, and further studies should focus on the enzymes that regulate the DHA hydrogenation pathway in the rumen.

\section{OTHER FACTOR}

\section{Fat-1 gene modification}

The Fat-1 gene is present in Caenorhabditis elegans, a free-living nematode. Spychalla, Kinney \& Browse (1997) first reported the fat-1 gene in Caenorhabditis elegans, and specifically expressed the gene in Arabidopsis, confirming the cDNA (complementary DNA) sequence of the fat- 1 gene. The translation product of the fat- 1 gene is n-3 PUFA dehydrogenase, which can catalyze the formation of the corresponding n-3 PUFA using 18-20 carbon n-6 PUFA as the substrate (Kang, 2005). The expression of the fat-1 gene can promote the synthesis of n-3 PUFA in nematodes. Liu et al. (2017) constructed the eukaryotic expression vector $p e f-g f p$ - 
284

fat-1, then transfected pef-gfp-fat-1 into cow fetal fibroblast cells and determined the fatty acid profile. They found that the expression of fat- 1 gene could increase the DHA concentration in the cells. The birth of transgenic cows that carried and expressed the mammalianized fat-1 gene (mfat-1) (Wu et al., 2012) and a transgenic cow showed increased n-3 PUFA profiles and reduced n-6 PUFA in their tissues and milk (Liu et al., 2017; Wu et al., 2012). The effect of the fat- 1 gene on the conversion of n-6 to n-3 PUFA was also confirmed in a transgenicpig model (Kang et al., 2004; Li et al., 2018). These findings need to be validated in a large cohort of transgenic animals to support these conclusions.

\section{CONCLUSIONS}

The literature is limited regarding the conversion of ALA to DHA in tissues and its effect on DHA content in milk. Many studies have focused on increasing the DHA concentration in milk by manipulation of the DHA supply in the diet. Many dietary factors can influence DHA's passage into milk and their effects need to be quantitated. The majority of dietary DHA is biohydrogenated in the rumen. It is extremely important to reduce our reliance on rumen biohydrogenation and find alternative means for synthesizing DHA.

The fat-1 gene from nematodes is highly effective in converting n-6 PUFA to n-3 PUFA. Since the gene does not exist in mammals, transgenic techniques have been applied, which have been successful in cows, pigs and mice. Thus, it may be worthwhile to examine enlarging the transgenic population.

\section{Acknowledgements}

We thank Professor Shimin Liu from the University of Western Australia for their advice. 
304

305

306

307

308

309

310

311

312

313

314

315

316

317

318

319

320

321

322

323

324

325

326

327

328

329

330

331

332

333

334

335

336

337

338

\section{References}

Abughazaleh AA, Ishlak A. 2014. Effects of incremental amounts of fish oil on trans fatty acids and b utyrivibrio bacteria in continuous culture fermenters. Journal of Animal Physiology and Animal Nutrition, 98 (2): 8 DOI 10.1194/jlr.M045450.

AbuGhazaleh AA, Schingoethe DJ, Hippen AR, Kalscheur KF, Whitlock LA. 2002. Fatty acid profiles of milk and rumen digesta from cows fed fish oil, extruded soybeans or their blend. Journal of Dairy Science, 85 (9) DOI 10.3168/jds.S0022-0302(02)74306-3.

Afshin A, Sur PJ, Fay KA, Cornaby L, Ferrara G, Salama J, Mullany EC, Abate KH, Abbafati C, Abebe Z, Afarideh M, Aggarwal A, Agrawal S, Akinyemiju T, Alahdab F, Bacha U, Bachman VF, Badali H, Badawi A, Bensenor IM, Bernabe E, Biadgilign S, Biryukov S, Cahill LE, Carrero JJ, Cercy K, Dandona L, Dandona R, Dang AK, Degefa MG, Zaki MES, Esteghamati A, Esteghamati S, Fanzo J, Farinha CSES, Farvid MS, Farzadfar F, Feigin VL, Fernandes JC, Flor LS, Foigt N, Forouzanfar MH, Ganji M, Geleijnse JM, Gillum RF, Goulart AC, Grosso G, Guessous I, Hamidi S, Hankey GJ, Harikrishnan S, Hassen HY, Hay SI, Hoang CL, Horino M, Islami F, Jackson MD, James SL, Johansson L, Jonas JB, Kasaeian A, Khader Y, Khalil IA, Khang Y, Kimokoti RW, Kokubo Y, Kumar GA, Lallukka T, Lopez A, Lorkowski S, Lotufo PA, Lozano R, Malekzadeh R, Marz W, Meier T, Melaku YA, Mendoza W, Mensink GBM, Micha R, Miller TR, Mirarefin M, Mohan V, Mokdad AH, Mozaffarian D, Nagel G, Naghavi M, Nguyen CT, Nixon MR, Ong KL, Pereira DM, Poustchi H, Qorbani M, Rai RK, Razogarcia C, Rehm CD, Rivera JA, Rodriguezramirez S, Roshandel G, Roth GA, Sanabria JR, Sanchezpimienta TG, Sartorius B, Schmidhuber J, Schutte AE, Sepanlou SG, Shin M, Sorensen RJD, Springmann M, Szponar L, Thornelyman AL, Thrift AG, Touvier M, Tran BX, Tyrovolas S, Ukwaja KN, Ullah I, Uthman OA, Vaezghasemi M, Vasankari T, Vollset SE, Vos T, Vu GT, Vu LG, Weiderpass EV, Werdecker A, Wijeratne T, Willett WC, Wu JHY, Xu G, Yonemoto N, Yu C, Murray CJL. 2019. Health effects of dietary risks in 195 countries, 1990-2017 a systematic analysis for the global burden of disease study 2017. The Lancet, 393:1958-1972 DOI 10.1016/S0140-6736(19)30041-8.

Aldai N, Delmonte P, Alves S, Bessa RJB, and Kramer J. 2018. Evidence for the initial steps of DHA biohydrogenation by mixed ruminal microorganisms from sheep involves formation of conjugated fatty acids. Journal of Agricultural and Food Chemistry, 66 (4):842-855 DOI 10.1021/acs.jafc.7b04563.

Alexander DD, Bylsma LC, Vargas AJ, Cohen SS, Doucette A, Mohamed M, Irvin SR, Miller PE, Watson HN, Fryzek JP. 2016. Dairy consumption and cvd: a systematic review and meta-analysis. British Journal of Nutrition, 115 (4):737-750 DOI 10.1017/S0007114515005000.

Al-Ghannami SS, Al-Adawi S, Ghebremeskel K. 2019. Randomised open-label trial of docosahexaenoic acid enriched fish oil and fish meal on cognitive and behavioural functioning in omani children. Nutrition, 57:167-172 DOI 10.1016/j.nut.2018.04.008

Altomonte I, Salari F, Licitra R, Martini M. 2018. Use of microalgae in ruminant nutrition and implications on 
milk quality-a review. Livestock Science, 214:25-35 DOI 10.1016/j.livsci.2018.05.006.

Aprianita A, Donkor ON, Moate PJ, Williams SR, Auldist MJ, Greenwood JS, Hannah MC, Wales WJ, Vasiljevic T. 2014. Effects of dietary cottonseed oil and tannin supplements on protein and fatty acid composition of bovine milk. Journal of Dairy Research, 81 (2):183-192 DOI 10.1017/s0022029914000065.

Baer RJ, Ryali J, Schingoethe DJ, Kasperson KM, Donovan DC, Hippen AR, Franklin ST. 2001. Composition and properties of milk and butter from cows fed fish oil 1. Journal of Dairy Science, 84 (2):345-353 DOI 10.3168/jds.S0022-0302(01)74483-9.

Bai Z1, Lee MRF, Ma L, Ledgard S, Oenema O, Velthof GL, Ma W, Guo M, Zhao Z, Wei S, Li S, Liu X, Havlík P, Luo J, Hu C, Zhang F. 2018. Global environmental costs of china's thirst for milk. Global Change Biology, 24 (5) DOI 10.1111/gcb.14047.

Bainbridge ML, Cersosimo LM, Wright AG, Kraft J. 2016. Rumen bacterial communities shift across a lactation in holstein, jersey and holstein $\times$ jersey dairy cows and correlate to rumen function, bacterial fatty acid composition and production parameters. Fems Microbiology Ecology, 92 (5) DOI 10.1093/femsec/fiw059.

Bianchi AC, Olazábal L, Torre A, Loperena L. 2014. Antarctic microorganisms as source of the omega-3 polyunsaturated fatty acids. World Journal of Microbiology \& Biotechnology, 30 (6):1869-1878 DOI 10.1007/s11274-014-1607-2.

Boeckaert C, Vlaeminck B, Dijkstra J, Issa-Zacharia A, Van Nespen T, Van Straalen W, Fievez V. 2008. Effect of dietary starch or micro algae supplementation on rumen fermentation and milk fatty acid composition of dairy cows. Journal of Dairy Science, 91 (12):4714-4727 DOI 10.3168/jds.2008-1178.

Burdge GC, Wootton SA. 2002. Conversion of $\alpha$-linolenic acid to eicosapentaenoic, docosapentaenoic and docosahexaenoic acids in young women. British Journal of Nutrition, 88 (4):10 DOI 10.1079/bjn2002689.

Casta Eda-Gutiérrez E, Veth MJD, Lock AL, Dwyer DA, Murphy KD, Bauman DE. 2007. Effect of supplementation with calcium salts of fish oil on n-3 fatty acids in milk fat. Journal of Dairy Science, 90 (9):4149-4156 DOI 10.3168/jds.2006-856.

Chilliard Y, Ferlay A, Doreau M. 2001. Effect of different types of forages, animal fat or marine oils in cow's diet on milk fat secretion and composition, especially conjugated linoleic acid (cla) and polyunsaturated fatty acids. Livestock Production Science, 70 (1):31-48 DOI 10.1016/s0301-6226(01)00196-8.

Chow TT, Fievez V, Moloney AP, Raes K, Demeyer D, Smet SD. 2004. Effect of fish oil on in vitro rumen lipolysis, apparent biohydrogenation of linoleic and linolenic acid and accumulation of biohydrogenation intermediates. Animal Feed Science \& Technology, 117 (1):1-12 DOI 10.1016/j.anifeedsci.2004.08.008.

Damude HG, Zhang H, Farrall L, Ripp KG, Tomb JF, Hollerbach D, Yadav NS. 2006. Identification of bifunctional delta-12/omega-3 fatty acid desaturases for improving the ratio of omega-3 to omega- 6 fatty acids in microbes and plants. Proceedings of the National Academy of Sciences of the United States of America, 103:9446-9451 DOI 10.1073/pnas.0511079103.

Benatar JR, Sidhu K, Stewart RAH. 2013. Effects of high and low fat dairy food on cardio-metabolic risk factors: a meta-analysis of randomized studies. PLoS One, 8(10):e76480 DOI 10.1371/journal.pone.0076480. 
375

376

377

378

379

380

381

382

383

384

385

386

387

388

389

390

391

392

393

394

395

396

397

398

399

400

401

402

403

404

405

406

407

408

409

410

Dongming X, Jackson EN, Quinn Z. 2015. Sustainable source of omega-3 eicosapentaenoic acid from metabolically engineered yarrowia lipolytica: from fundamental research to commercial production. Appl Microbiol Biotechnol, 99 (4):1599-1610 DOI 10.1007/s00253-014-6318-y.

Donovan DC, Schingoethe DJ, Baer RJ, Ryali J, Hippen AR, Franklin ST. 2000. Influence of dietary fish oil on conjugated linoleic acid and other fatty acids in milk fat from lactating dairy cows. Journal of Dairy Science, 83 (11):2620-2628 DOI 10.3168/jds.s0022-0302(00)75155-1.

Doreau M, Ferlay A. 1994. Digestion and utilisation of fatty acids by ruminants. Anim.feed Sci.technol, 45 (34):379-396 DOI 0.1016/0377-8401(94)90039-6

Edwards HD, Anderson RC, Miller RK, Taylor TM, Hardin MD, Smith SB. et al. 2012. Glycerol inhibition of ruminal lipolysis in vitro. Journal of Dairy Science, 95 (9):5176-5181 DOI 10.3168/jds.2011-5236.

Edwards HD, Anderson RC, Taylor TM, Miller RK, Hardin MD, Nisbet DJ, Krueger NA, Smith SB. 2013. Interactions between oil substrates and glucose on pure cultures of ruminal lipase-producing bacteria. Lipids, 48 (7):749-755 DOI 10.1007/s11745-013-3793-3.

Engel S, Elhauge M, Tholstrup T. 2017. Effect of whole milk compared with skimmed milk on fasting blood lipids in healthy adults: a 3 -week randomized crossover study. European Journal of Clinical Nutrition, 72 (2), 249-254 DOI 10.1038/s41430-017-0042-5.

Escobar M, Vlaeminck B, Jeyanathan J, Thanh LP, Shingfield KJ, Wallace RJ, Fievez V. 2016. Effect of adsorbants on in vitro biohydrogenation of $22: 6 n-3$ by mixed cultures of rumen microorganisms. Animal, 10 (9):1439-1447 DOI 10.1017/s1751731116000367.

Fleming JA, Kris-Etherton PM. 2014. The evidence for $\alpha$-linolenic acid and cardiovascular disease benefits: comparisons with eicosapentaenoic acid and docosahexaenoic acid. Advances in Nutrition, 5 (6):863S876S. DOI 10.3945/an.114.005850.

Fougère H, Delavaud C, Bernard L. 2018. Diets supplemented with starch and corn oil, marine algae, or hydrogenated palm oil differentially modulate milk fat secretion and composition in cows and goats: a comparative study. Journal of Dairy Science, 101 (9):8429-8445 DOI 10.3168/jds.2018-14483.

Franklin ST, Martin KR, Baer RJ, Schingoethe DJ, Hippen AR. 1999. Dietary marine algae (schizochytrium sp.) Increases concentrations of conjugated linoleic, docosahexaenoic and transvaccenic acids in milk of dairy cows. Journal of Nutrition, 129 (11):2048-2054 DOI 10.1093/jn/129.11.2048.

Gázquez AHIL. 2017. Docosahexaenoic acid supplementation during pregnancy as phospholipids did not improve the incorporation of this fatty acid into rat fetal brain compared with the triglyceride form. Nutrition Research, 37, 78-86.

DOI 10.1016/j.nutres.2016.12.006.

Gebauer SK, Psota TL, Harris WS, Kris-Etherton PM. 2006. N-3 fatty acid dietary recommendations and food sources to achieve essentiality and cardiovascular benefits. American Journal of Clinical Nutrition, 83 (6 Suppl):1526S-1535S DOI 10.1186/1476-511X-5-14.

Gholami H, Chamani M, Towhidi A, Fazeli MH. 2010. Effect of feeding a docosahexaenoic acid-enriched

Peer) reviewing PDF | (2020:04:48138:1:1:NEW 31 Aug 2020) 
411

412

413

414

415

416

417

418

419

420

421

422

423

424

425

426

427

428

429

430

431

432

433

434

435

436

437

438

439

440

441

442

443

444

445

446

nutriceutical on the quality of fresh and frozen-thawed semen in holstein bulls. Theriogenology, 74 (9):1548-1558 DOI 10.1016/j.theriogenology.2010.06.025.

Gibson RA, Muhlhausler B, Makrides M. 2015. Conversion of linoleic acid and alpha-linolenic acid to longchain polyunsaturated fatty acids (lcpufas), with a focus on pregnancy, lactation and the first 2 years of life. Maternal and Child Nutrition, 7 (s2):17-26. DOI 10.1111/j.1740-8709.2011.00299.x.

Gong Y, Wan X, Jiang M, Hu C, Hu H, Huang F. (2014). Metabolic engineering of microorganisms to produce omega-3 very long-chain polyunsaturated fatty acids. Progress in Lipid Research, 56:19-35 DOI 10.1016/j.plipres.2014.07.001.

Hashimoto M, Hossain S, Mamun AA, Matsuzaki K, Arai H. 2017. Docosahexaenoic acid: one molecule diverse functions. Critical Reviews in Biotechnology, 37 (5):579-597 DOI 10.1080/07388551.2016.1207153.

Hungate RE. 1966. The rumen and its microbes.London: Blackie Academic and Professional Press. DOI 10.1016/B978-1-4832-3308-6.50016-4.

Ishaq Z, Nawaz MA. 2018. Analysis of contaminated milk with organochlorine pesticide residues using gas chromatography. International Journal of Food Properties 1.21:879-891 DOI 10.1080/10942912.2018.1460607.

Jaglan N, Kumar S, Choudhury PK, Tyagi B, \& Tyagi AK. 2019. Isolation, characterization and CLA production potential of bifidobacterial isolates from ruminal fluid samples of Murrah buffaloes. Anaerobe DOI 10.1016/j.anaerobe.2019.02.001

Jami E, Israel A, Kotser A, Mizrahi I. 2013. Exploring the bovine rumen bacterial community from birth to adulthood. Isme Journal, 7 (6):1069-1079 DOI 10.1038/ismej.2013.2.

Jenkins TC, Wallace RJ, Moate PJ, Mosley EE. 2007. Board-invited review: recent advances in biohydrogenation of unsaturated fatty acids within the rumen microbial ecosystem. Journal of Animal Science, 86 (2):397-412 DOI 10.2527/jas.2007-0588.

Jeyanathan J, Escobar M, Wallace RJ, Fievez V, Vlaeminck B. 2016. Biohydrogenation of 22:6n-3 by butyrivibrio proteoclasticus p18. Bmc Microbiology, 16 (1) DOI 10.1186/s12866-016-0720-9.

Johnson SB, Kramer TR, Briske-Anderson M, Holman RT. 1989. Fatty acid pattern of tissue phospholipids in copper and iron deficiencies. Lipids, 24 (2):141-145 DOI 10.1007/BF02535252.

Kabeya N, Fonseca MM, Ferrier DEK, Navarro JC, Bay LK, Francis DS, Tocher DR, Castro LFC, Monroig Ó. 2018. Genes for de novo biosynthesis of omega-3 polyunsaturated fatty acids are widespread in animals. Science Advances, 4 (5):r6849 DOI 10.1126/sciadv.aar6849.

Kairenius P, Ärölä A, Leskinen H, Toivonen V, Ahvenjärvi S, Vanhatalo A, Huhtanen P, Hurme T, Griinari JM, Shingfield KJ. 2015. Dietary fish oil supplements depress milk fat yield and alter milk fatty acid composition in lactating cows fed grass silage-based diets. Journal of Dairy Science, 98 (8):5653-5671 DOI $10.3168 /$ jds.2015-9548.

Kairenius P, Leskinen H, Toivonen V, Muetzel S, Ahvenjärvi S, Vanhatalo A, Huhtanen P, Wallace RJ, Shingfield KJ. 2018. Effect of dietary fish oil supplements alone or in combination with sunflower and 
linseed oil on ruminal lipid metabolism and bacterial populations in lactating cows. Journal of Dairy Science, 101 (4):S1331039752 DOI 10.3168/jds.2017-13776.

Kairenius P, Toivonen V, Shingfield KJ. 2011. Identification and ruminal outflow of long-chain fatty acid biohydrogenation intermediates in cows fed diets containing fish oil. Lipids, 46 (7):587 DOI 10.1007/s11745-011-3561-1.

Kang JX. 2005. From fat to fat-1: a tale of omega-3 fatty acids. Journal of Membrane Biology, 206 (2):165-172 DOI 10.1007/s00232-005-0790-3.

Kang JX, Wang J, Wu L, Kang ZB. 2004. Transgenic mice: fat-1 mice convert n-6 to n-3 fatty acids. Nature, 427 (6974):504 DOI 10.1038/427504a.

Kepler CR, Hirons KP, Mcneill JJ, Tove SB. 1966. Intermediates and products of the biohydrogenation of linoleic acid by butyrivibrio fibrisolvens. Journal of Biological Chemistry, 241 (6):1350-1354.

Kim EJ, Huws SA, Lee MR, Wood JD, Muetzel SM, Wallace RJ, Scollan ND. 2008. Fish oil increases the duodenal flow of long chain polyunsaturated fatty acids and trans-11 18:1 and decreases 18:0 in steers via changes in the rumen bacterial community. Journal of Nutrition, 138 (5), 889 DOI 10.1359/jbmr.2000.15.7.1243.

Kim KB, Nam YA, Kim HS, Hayes AW, Lee BM. 2014. $\alpha$-Linolenic acid: nutraceutical, pharmacological and toxicological evaluation. Food \& Chemical Toxicology, 70:163-178 DOI 10.1016/j.fct.2014.05.009.

Lacasse P, Kennelly JJ, Delbecchi L, Ahmadi CE. 2002. Addition of protected and unprotected fish oil to diets for dairy cows. I. Effects on the yield, composition and taste of milk. Journal of Dairy Research, 69 (4):511520 DOI 10.1017/s0022029902005770.

Li M, Ouyang H, Yuan H, Li J, Xie Z, Wang K, Yu T, Liu M, Chen X, Tang X, Jiao H, Pang D. 2018. Sitespecific fat-1 knock-in enables significant decrease of n-6pufas/n-3pufas ratio in pigs. G3 (Bethesda, Md.), 8 (5):1747-1754 DOI 10.1534/g3.118.200114.

Liu XF, Wei ZY, Bai CL, Ding XB, Li X, Su GH, Cheng L, Zhang L, Guo H, Li GP. 2017. Insights into the function of n-3 pufas in fat-1 transgenic cattle. Journal of Lipid Research, 58 (8):1524-1535 DOI 10.1194/jlr.M072983.

Livingstone KM, Humphries DJ, Kirton P, Kliem KE, Givens DI, Reynolds CK. 2015. Effects of forage type and extruded linseed supplementation on methane production and milk fatty acid composition of lactating dairy cows. Journal of Dairy Science, 98 (6):4000-4011 DOI 10.3168/jds.2014-8987.

Louren OM, Ramos-Morales E, Wallace RJ. 2010. The role of microbes in rumen lipolysis and biohydrogenation and their manipulation. Animal An International Journal of Animal Bioscience, 4 (7):1008-1023 DOI $10.1017 / \mathrm{S} 175173111000042 \mathrm{X}$.

Madeira MS, Carlos C, Lopes PA, DiogoCoelho C, Bandarra NM, Prates JAM. 2017. Microalgae as feed ingredients for livestock production and meat quality: a review. Livestock Science, 205:111-121 DOI 10.1016/j.livsci.2017.09.020.

Mahla AS, Chaudhari RK, Verma AK, Singh AK, Singh SK, Singh G, Sarkar M, Dutta N, Kumar H, 
Krishnaswamy N. 2017. Effect of dietary supplementation of omega-3 polyunsaturated fatty acid (pufa) rich fish oil on reproductive performance of the goat (capra hircus). Theriogenology, 99. DOI 10.1016/j.theriogenology.2017.05.023.

Maia MRG, Chaudhary LC, Figueres L, Wallace RJ. 2007. Metabolism of polyunsaturated fatty acids and their toxicity to the microflora of the rumen. Antonie van Leeuwenhoek, 91 (4):303-314 DOI 10.1007/s10482006-9118-2.

Maia MR, Chaudhary LC, Bestwick CS, Richardson AJ, McKain N, Larson TR, Graham IA, Wallace RJ. 2010. Toxicity of unsaturated fatty acids to the biohydrogenating ruminal bacterium, butyrivibrio fibrisolvens. Bmc Microbiology, 10 (1):52 DOI 10.1186/1471-2180-10-52.

MacGibbon AKH \& Taylor MW. 2006. Composition and Structure of Bovine Milk Lipids. Advanced Dairy Chemistry Volume 2 Lipids, 1-42 DOI 10.1007/0-387-28813-9_1

Mattos R, Staples CR, Arteche A, Wiltbank MC, Diaz FJ, Jenkins TC, Thatcher WW. 2004. The effects of feeding fish oil on uterine secretion of pgf2alpha, milk composition, and metabolic status of periparturient holstein cows. Journal of Dairy Science, 87 (4):921-932 DOI 10.3168/jds.s0022-0302(04)73236-1.

Miller M, Stone NJ, Ballantyne C, Bittner V, Criqui MH, Ginsberg HN, Goldberg AC, Howard WJ, Jacobson MS, Kris-Etherton PM, Lennie TA, Levi M, Mazzone T, Pennathur S. 2011. Triglycerides and cardiovascular disease: a scientific statement from the american heart association. Circulation, 123 (20):2292-2333 DOI 10.1161/CIR.0b013e3182160726.

Missotten J, Smet SD, Raes K, Doran O. 2009. Effect of supplementation of the maternal diet with fish oil or linseed oil on fatty-acid composition and expression of $\Delta 5$ - and $\Delta 6$-desaturase in tissues of female piglets. Animal An International Journal of Animal Bioscience, 3 (8):1196-1204 DOI $10.1017 /$ S1751731109004455.

Moate PJ, Williams SR, Hannah MC, Eckard RJ, Auldist MJ, Ribaux BE, Jacobs JL, Wales WJ. 2013. Effects of feeding algal meal high in docosahexaenoic acid on feed intake, milk production, and methane emissions in dairy cows. Journal of Dairy Science, 96 (5):3177-3188 DOI 10.3168/jds.2012-6168.

Moraïs S, Mizrahi I. 2019. The road not taken: the rumen microbiome, functional groups, and community states. Trends in Microbiology, 27 (6):538-549. DOI 10.1016/j.tim.2018.12.011.

Moran CA, Morlacchini M, Keegan JD, Fusconi G. 2018. The effect of dietary supplementation with aurantiochytrium limacinum on lactating dairy cows in terms of animal health, productivity and milk composition. Journal of Animal Physiology \& Animal Nutrition, 102 (2):1-15. DOI 10.1111/jpn.12827.

Mozaffarian D, Wu J. 2018. Flavonoids, dairy foods, and cardiovascular and metabolic health: a review of emerging biologic pathways. Circulation Research, 122 (2), 369. DOI 10.1161/CIRCRESAHA.117.309008.

Narce M, Poisson JP, Belleville J, Chanussot B. 1988. Time-course effects of protein malnutrition on hepatic fatty acids $\Delta 6$ and $\Delta 5$ desaturation in the growing rat. British Journal of Nutrition, 60:389-402 DOI $10.1079 /$ bjn 19880108 . 
Neuringer M, Anderson GJ, Connor WE. 1988. The essentiality of n-3 fatty acids for the development and function of the retina and brain. Annual Review of Nutrition, 8 (1), 517. DOI 10.1146/annurev.nu.08.070188.002505.

Organization WH. 2008. Interim summary of conclusions and dietary recommendations on total fat \& fatty acids. From the joint FAO/WHO expert consultation on fats and fatty acids in human nutrition, 10-14.

Petri RM, Mapiye C, Dugan ME, Mcallister TA. 2014. Subcutaneous adipose fatty acid profiles and related rumen bacterial populations of steers fed red clover or grass hay diets containing flax or sunflower-seed. Plos One, 9 (8):e104167 DOI 10.1371/journal.pone.0104167.

Pi Y, Gao ST, Ma L, Zhu YX, Wang JQ, Zhang JM, Xu JC, Bu DP. 2016. Effectiveness of rubber seed oil and flaxseed oil to enhance the $\alpha$-linolenic acid content in milk from dairy cows. Journal of Dairy Science, 99 (7):5719-5730 DOI 10.3168/jds.2015-9307.

Pirondini M, Colombini S, Mele M, Malagutti L, Rapetti L, Galassi G, Crovetto GM. 2015. Effect of dietary starch concentration and fish oil supplementation on milk yield and composition, diet digestibility, and methane emissions in lactating dairy cows. Journal of Dairy Science, 98 (1):357-372. DOI 10.3168/jds.2014-8092.

Plourde M, Cunnane SC. 2007. Extremely limited synthesis of long chain polyunsaturates in adults: implications for their dietary essentiality and use as supplements. Applied Physiology, Nutrition, and Metabolism, 32 (4):619-634 DOI 10.1139/H07-034.

Póti P, Pajor F, Bodnár Á, Penksza K. Köles P. 2015. Effect of micro-alga supplementation on goat and cow milk fatty acid composition. Chilean Journal of Agricultural Research, 75 (2):259-263 DOI 10.4067/S071858392015000200017.

Prakasan P, Unni KN, Sajith S. Sailas B. 2013. Candida tropicalis bpu1, a novel isolate from the rumen of the malabari goat, is a dual producer of biosurfactant and polyhydroxybutyrate. Yeast, 30 (3):103-110 DOI 10.1002/yea.2944.

Priji P, Sajith S, Unni KN, Anderson RC, Benjamin S. 2017. Pseudomonas sp. Bup6, a novel isolate from malabari goat produces an efficient rhamnolipid type biosurfactant. Journal of Basic Microbiology, 57 (1):21-33 DOI 10.1002/jobm.201600158.

Privé F, Kaderbhai NN, Girdwood S, Worgan HJ, Pinloche E, Scollan ND, Huws SA, Newbold CJ. 2013. Identification and characterization of three novel lipases belonging to families ii and $\mathrm{v}$ from anaerovibrio lipolyticus 5st. Plos One, 8 (8) DOI 69076.10.1371/journal.pone.0069076.

Priyadarshani I, Rath, B. 2012. Commercial and industrial applications of micro algae-a review. J algal biomass utln, 3 (4), 89-100.

Qin L, Xu J, Han S, Zheng Z, Zhao Y, Szeto IM. 2015. Dairy consumption and risk of cardiovascular disease: an updated meta-analysis of prospective cohort studies. Asia Pacific Journal of Clinical Nutrition, 24 (1):90100 DOI 10.6133/apjen.2015.24.1.09.

Ramaswamy N, Baer RJ, Schingoethe DJ, Hippen AR, Kasperson KM, Whitlock LA. 2001. Composition and 
flavor of milk and butter from cows fed fish oil, extruded soybeans, or their combination1. Journal of Dairy Science, 84 (10):2144-2151 DOI 10.3168/jds.S0022-0302(01)74659-0.

Rietsema S, Eelderink C, Joustra ML, Van V, Iris MY, Van Londen, M, Corpeleijn E, Singh-Povel CM, Geurts JMW, Kootstra-Ros JE, Westerhuis R, Navis G, Bakker SJL. 2019. Effect of high compared with low dairy intake on blood pressure in overweight middle-aged adults: results of a randomized crossover intervention study. The American Journal of Clinical Nutrition, 110(2), 340348. DOI 10.1093/ajcn/nqz116.

Russell JB, and Rychlik JL. 2001. Factors that alter rumen microbial ecology. Science, 292 (5519):1119-1122 DOI 10.1126/science.1058830.

Ryckebosch E, Bruneel C, Termote-Verhalle R, Goiris K, Muylaert K, Foubert I. 2014. Nutritional evaluation of microalgae oils rich in omega-3 long chain polyunsaturated fatty acids as an alternative for fish oil. Food Chemistry, 160 (1):393-400 DOI 10.1016/j.foodchem.2014.03.087.

Saini RK, Keum YS. 2018. Omega-3 and omega-6 polyunsaturated fatty acids: dietary sources, metabolism, and significance - a review. Life Sciences, 203:255-267 DOI 10.1016/j.lfs.2018.04.049.

Sakurama H, Kishino S, Mihara K, Ando A, Ogawa J. 2014. Biohydrogenation of c-20 polyunsaturated fatty acids by anaerobic bacteria. Journal of Lipid Research, 55 (9):1855-1863 DOI 10.1194/jlr.M045450.

Sargolzehi MM, Naserian A, Asoodeh A, Roknabadi MR, Shin JS, Ghassemi NJ. 2015. Short communication application of esterase inhibitors: a possible new approach to protect unsaturated fatty acids from ruminal biohydrogenation. European Journal of Lipid Science and Technology, 117 (10):1667-1672 DOI 10.1002/ejlt.201400567.

Scollan ND, Choi NJ, Kurt E, Fisher AV, Enser M, Wood JD. 2001a Manipulating the fatty acid composition of muscle and adipose tissue in beef cattle. Br J Nutr, 85 (1), 115-124 DOI 10.1079/bjn2000223.

Scollan ND, Dhanoa MS, Choi NJ, Maeng WJ, Enser M, Wood JD. 2001b. Biohydrogenation and digestion of long chain fatty acids in steers fed on different sources of lipid. Journal of Agricultural Science, 136 (5):345355 DOI 10.1017/S0021859601008796.

Shingfield K J, Ahvenjarvi S, Toivonen V, Arola A, Nurmela K V V, Huhtanen P, Griinari J M. 2003. Effect of dietary fish oil on biohydrogenation of fatty acids and milk fatty acid content in cows. Animal Science, 77 (4), 165-179 DOI 10.1017/S1357729800053765.

Shingfield KJ, Bonnet M, Scollan ND. 2013. Recent developments in altering the fatty acid composition of ruminant-derived foods. Animal, 7 (s1):132-162 DOI 10.1017/s1751731112001681.

Shingfield KJ, Kairenius P, Arölä A, Paillard D, Muetzel S, Ahvenjärvi S, Vanhatalo A, Huhtanen P, Toivonen V, Griinari JM, Wallace RJ. 2012. Dietary fish oil supplements modify ruminal biohydrogenation, alter the flow of fatty acids at the omasum, and induce changes in the ruminal butyrivibrio population in lactating cows. Journal of Nutrition, 142 (8):1437-1448 DOI 10.3945/jn.112.158576.

Shingfield KJ, Lee MRF, Humphries DJ, Scollan ND, Toivonen V, Beever DE, Reynolds CK.2011. Effect of linseed oil and fish oil alone or as an equal mixture on ruminal fatty acid metabolism in growing steers fed 
maize silage-based diets. Journal of Animal Science, 89 (11):3728-3741 DOI 10.2527/jas.2011-4047.

Shingfield KJ, Reynolds CK, Hervás G, Griinari JM, Grandison AS, Beever DE. 2006. Examination of the persistency of milk fatty acid composition responses to fish oil and sunflower oil in the diet of dairy cows. Journal of Dairy Science, 89 (2):714-732 DOI 10.3168/jds.s0022-0302(06)72134-8.

Shinji F, Yumiko N, Eisuke C, Hiroshi O, Tsuneo H, Jun K. 2009. Evaluation and characterization of bacterial metabolic dynamics with a novel profiling technique, real-time metabolotyping. Plos One, 4 (3):e4893 DOI 10.1371/journal.pone.0004893.

Sinedino LDP, Honda PM, Souza LRL, Lock AL, Santos JEP. 2017. Effects of supplementation with docosahexaenoic acid on reproduction of dairy cows. Reproduction, 153 (5):707-723 DOI 10.1530/REP16-0642.

Spychalla JP, Kinney AJ, Browse J. 2007. Identification of an animal v-3 fatty acid desaturase by heterologous expression in Arabidopsis. PNAS, 94:1142-1147.

Stamey JA, Shepherd DM, Veth MJD, Corl BA. 2012. Use of algae or algal oil rich in n-3 fatty acids as a feed supplement for dairy cattle. Journal of Dairy Science, 95 (9):5269-5275 DOI 10.3168/jds.2012-5412.

Swanson D, Block R, Mousa SA. 2012. Omega-3 fatty acids epa and dha: health benefits throughout life. Advances in Nutrition, 3 (1):1. DOI 10.3945/an.111.000893.

Toral PG, Hervás G, Leskinen H, Shingfield KJ, Frutos P. 2018. In vitro ruminal biohydrogenation of eicosapentaenoic (EPA), docosapentaenoic (DPA), and docosahexaenoic acid (DHA) in cows and ewes: intermediate metabolites and pathways. Journal of Dairy Science, 101 (7). DOI 10.3168/jds.2017-14183.

USA, NRC. S. 2001. Nutrient requirements of dairy cattle.

Vafa TS., Naserian AA, Moussavi ARH, Reza V, Mohsen DM. 2012. Effect of supplementation of fish and canola oil in the diet on milk fatty acid composition in early lactating holstein cows. Asian-Australasian Journal of Animal Sciences, 25 (3):311-319 DOI 10.5713/ajas.2010.10014.

Vahmani P, Fredeen AH, Glover KE. 2013. Effect of supplementation with fish oil or microalgae on fatty acid composition of milk from cows managed in confinement or pasture systems. Journal of Dairy Science, 96 (10):6660-6670 DOI 10.3168/jds.2013-6914.

Wachira AM, Sinclair LA, Wilkinson RG, Hallett K, Enser M, Wood JD. 2000. Rumen biohydrogenation of n3 polyunsaturated fatty acids and their effects on microbial efficiency and nutrient digestibility in sheep. Journal of Agricultural Science, 135 (4):419-428 DOI 10.1017/s0021859699008370.

Wasowska I, Maia MRG, Nied Wiedzka KM, Czauderna M, Ribeiro JMCR, Devillard E. et al. 2006. Influence of fish oil on ruminal biohydrogenation of c18 unsaturated fatty acids. British Journal of Nutrition, 95 (6):1199-1211 DOI 10.1079/bjn20061783.

Whitlock LA, Schingoethe DJ, Hippen AR, Kalscheur KF, Baer RJ, Ramaswamy N, Kasperson KM. 2002. Fish oil and extruded soybeans fed in combination increase conjugated linoleic acids in milk of dairy cows more than when fed separately. Journal of Dairy Science, 85 (1):234-243 DOI 10.3168/jds.S00220302(02)74072-1. 
627 Wu X, Ouyang H, Duan B, Pang D, Zhang L, Yuan T, Xue L, Ni D, Cheng L, Dong S, Wei Z, Li L, Yu M, Sun 628 QY, Chen DY, Lai L, Dai Y, Li GP. 2012. Production of cloned transgenic cow expressing omega-3 fatty acids. Transgenic Research, 21 (3):537-543 DOI 10.1007/s11248-011-9554-2.

630 Xiang M, Rahman MA, Ai H, Li X, Harbige LS. 2006. Diet and gene expression- delta-5 and delta-6 desaturases 631 in healthy chinese and european subjects. Annals of Nutrition and Metabolism, 50 (6):492-498 DOI $632 \quad 10.1159 / 000095829$.

633 Xue ZX, Sharpe PL, Hong SP, Yadav NS, Xie DM, Short DR, Damude HG, Rupert RA, Seip JE, Wang J, Pollak DW, Bostick MW, Bosak MD, Macool DJ, Hollerbach DH, Zhang HX, Arcilla DM, Bledsoe SA, Croker K, McCord EF, Tyreus BD, Jackson EN, Zhu Q. 2013. Production of omega-3 eicosapentaenoic acid by metabolic engineering of yarrowia lipolytica. Nature Biotechnology, 31 (8):734-740 DOI $10.1038 /$ nbt.2622.

639

Zhao S, Wang J, Zheng N, Bu D, Sun P, Yu Z. 2015. Reducing microbial ureolytic activity in the rumen by immunization against urease therein. Bmc Veterinary Research, 11 (1). DOI 10.1186/s12917-015-0409-6. 
Figure 1

Biosynthetic conversion pathway of ALA to DHA

Biosynthetic conversion pathway of ALA to DHA. Abbreviations: ALA, $\alpha$-linolenic acid; EPA, eicosapentaenoic acid; DHA, docosahexaenoic acid. The first step that ALA is converted to stearidonic acid (C18:4-3n) is a rate-limiting reaction. The Figure is adapted from Kabeya et al. (2018) and Kim et al., (2014). 


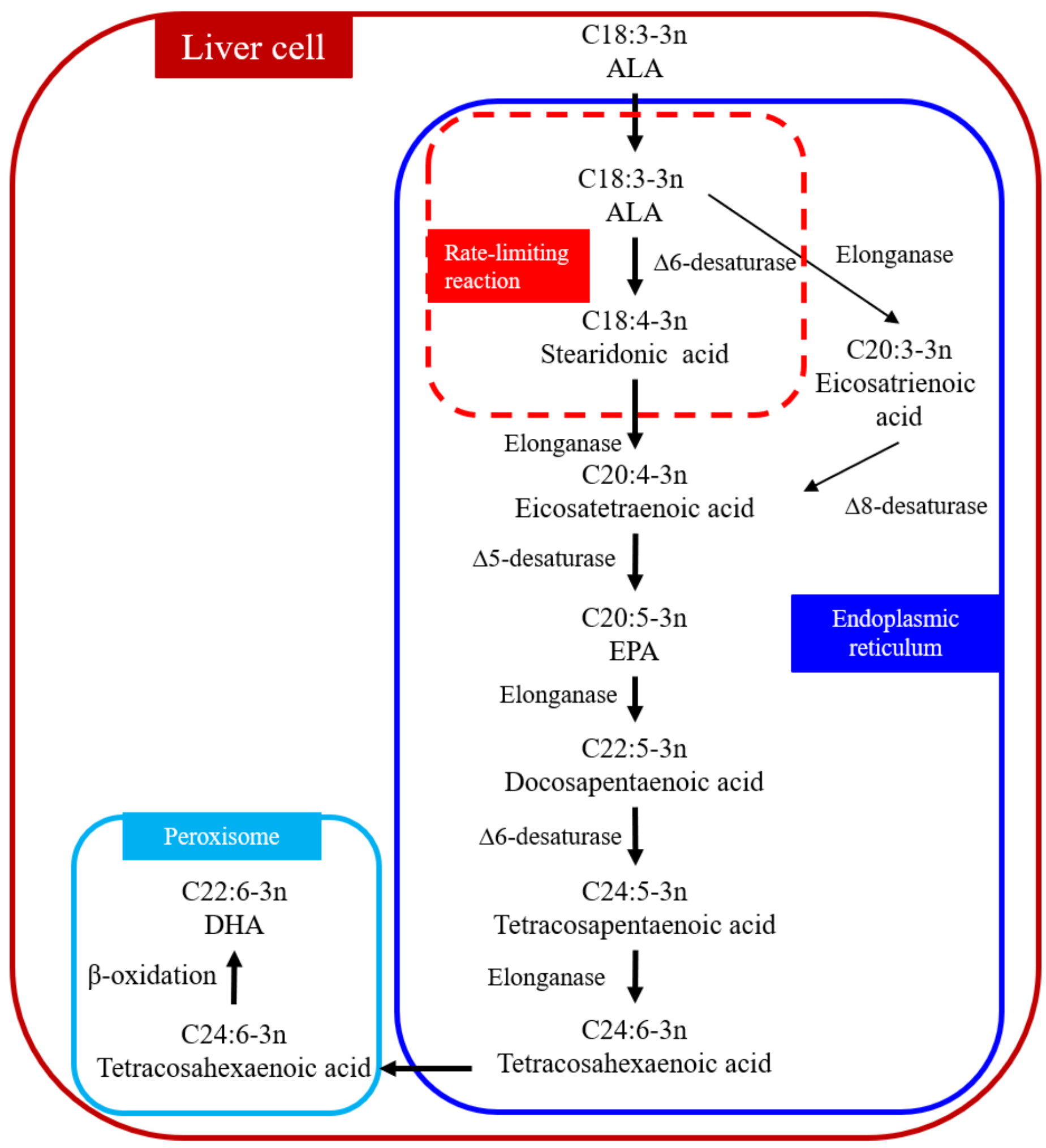


Figure 2

The pathway of DHA transportation into milk

The pathway of DHA transportation into milk. Abbreviations: DHA, docosahexaenoic acid. The Figure is adapted from Shingfield et al. (2003), NRC (USA, 2001), Wachira et al. (2000) and Mattos et al. (2004). 


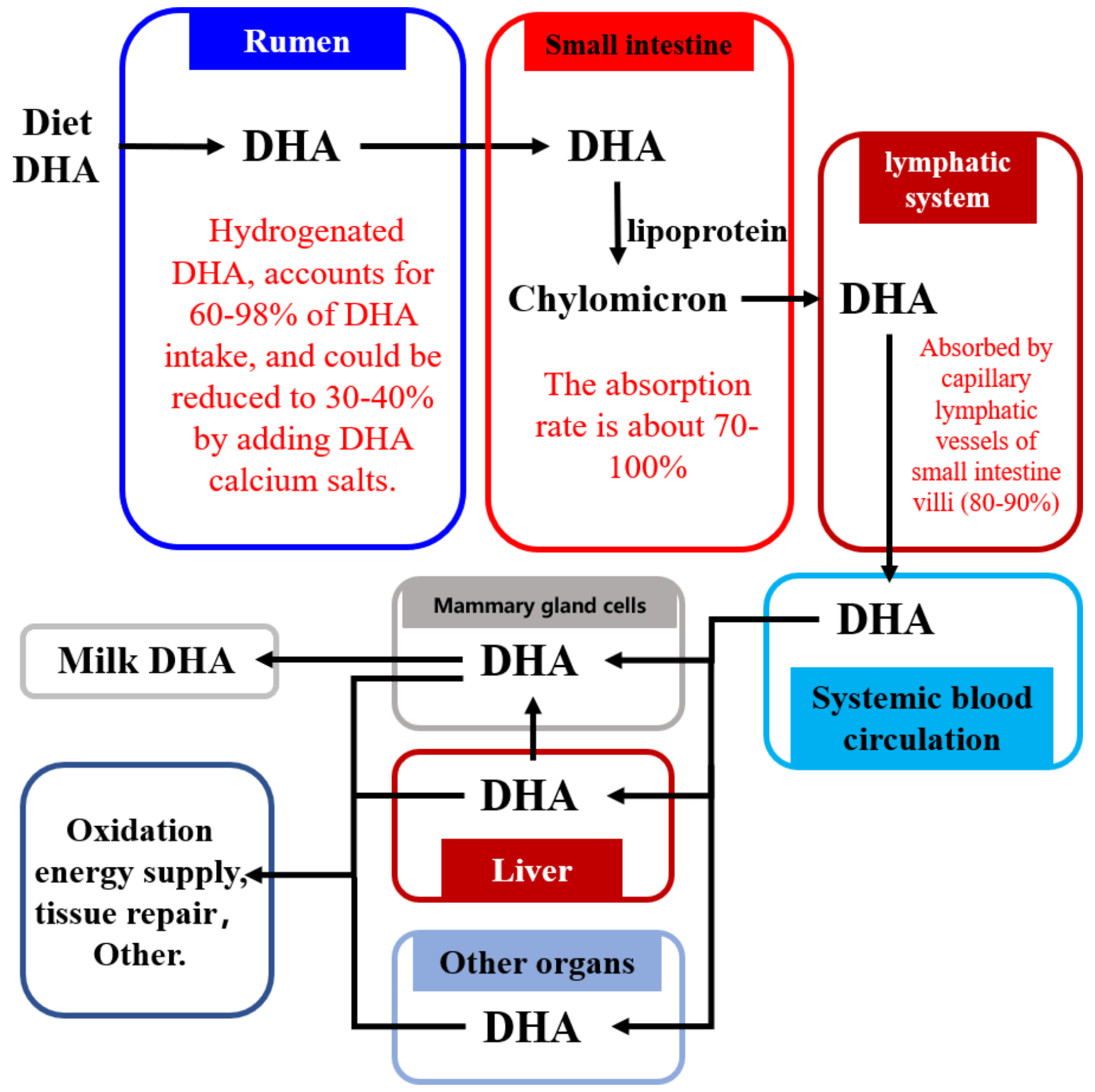




\section{Figure 3}

The putative biohydrogenation pathway of DHA in the rumen

The putative biohydrogenation pathway of DHA in the rumen. Abbreviations: DHA, docosahexaenoic acid, C22:6 cis-4,cis-7,cis-10,cis-13,cis-16,cis-19. The arrows represent possible major pathways. Neither all putative fatty acids nor the numerous interconversions among C22:6 isomers are presented. The Figure is adapted from Kairenius et al. (2018), Shingfield et al. (2012), Jenkins et al., (2007) and Aldai et al., (2018) and Jeyanathan et al., (2016). 


\section{C22:6 cis-4,cis-7,cis-10,cis-13,cis-16,cis-19}

$\sqrt{2}$

C22:6 trans-5,cis-7,cis-10,cis-13,cis-16,cis-19

$\checkmark$

C22:5 cis- 7 ,cis-10,cis-13,cis-16,cis-19

\section{C22:4 cis-10,cis-13,cis-16,cis-19}

$\checkmark$

C22:3 cis-13,cis-16,cis-19
C22:3 cis-10,cis-13,cis-16

\section{C22:2 cis-13,cis-16}

C22:1 cis-13

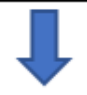

C22:0 


\section{Table $\mathbf{1}$ (on next page)}

The effects of dietary supplementation of fish oil on milk fat content

Fatty acid $\approx$ triacylglycerols + diacylglycerols + monoacylglycerols + free fatty acids. Milk fatty acid $=$ milk fat content $\times 99.13 \%$ ( MacGibbon $\&$ Taylor 2006) . C=control; $\mathrm{Ca}, \mathrm{b}=$ controls in article; $T a, b=$ treatments in article; $T 1$, 2, 3=treatments. RPFO: rumen protected fish oil; RUFO: rumen unprotected fish oil. ND: Not detected. 
1 Table 1. The effects of dietary supplementation of fish oil on milk fat content

\begin{tabular}{|c|c|c|c|c|c|c|}
\hline Treatment & $\begin{array}{c}\text { Fish oil } \\
\text { supplement }\end{array}$ & $\begin{array}{l}\text { Diet DHA } \\
\text { intake }(g / d)\end{array}$ & $\begin{array}{l}\text { Milk fatty acid } \\
\text { conten }(\%)\end{array}$ & $\begin{array}{l}\text { DHA content } \\
\text { in milk }(\mathrm{g} / \mathrm{d})\end{array}$ & $\begin{array}{l}\text { Increase of DHA content in } \\
\text { milk (compared with control } \\
\text { group) }(\mathrm{g} / \mathrm{d})\end{array}$ & Reference \\
\hline $\mathrm{C}=$ basal diet & - & - & 3.52 & 0.26 & - & $\begin{array}{l}\text { Vahmani, Fredeen \& Glover, } \\
2013\end{array}$ \\
\hline $\mathrm{T}=$ basal diet + RUFO & $200 \mathrm{~g} / \mathrm{d}$ & 24.7 & 3.37 & 1.68 & 1.42 & \\
\hline $\mathrm{Ca}=$ basal diet & - & 0.00 & 4.30 & 0.00 & - & Pirondini et al., 2015 \\
\hline $\mathrm{Ta}=$ basal diet + RUFO & $0.80 \%$ & 17.6 & 4.51 & 0.40 & 0.40 & \\
\hline $\mathrm{C}=$ basal diet & - & 0.21 & 3.46 & 0.40 & - & AbuGhazaleh et al., 2002 \\
\hline $\mathrm{T} 1=$ basal diet + RUFO & $2.00 \%$ & 21.3 & 3.22 & 2.49 & 2.09 & \\
\hline $\mathrm{T} 2=$ basal diet + RUFO & $1.00 \%$ & 12.2 & 3.45 & 1.46 & 1.06 & \\
\hline $\mathrm{C}=$ basal diet & - & ND & 3.28 & ND & - & Ramaswamy et al., 2001 \\
\hline $\mathrm{T}=$ basal diet + RUFO & $2.00 \%$ & ND & 2.56 & ND & - & \\
\hline $\mathrm{C}=$ basal diet & - & 0.35 & 3.40 & 0.47 & - & Vafa et al., 2012 \\
\hline $\mathrm{T} 1=$ basal diet + RUFO & $2.00 \%$ & 31.7 & 2.30 & 2.18 & 1.71 & \\
\hline $\mathrm{T} 2=$ basal diet + RUFO & $1.00 \%$ & 12.9 & 2.45 & 0.84 & 0.37 & \\
\hline $\mathrm{Ca}=$ basal diet & - & - & 3.48 & 0.56 & - & Whitlock et al., 2002 \\
\hline Ta1=basal diet + RUFO & $2.00 \%$ & 11.1 & 2.87 & 1.59 & 1.03 & \\
\hline $\mathrm{Ta} 2=$ basal diet + RUFO & $1.00 \%$ & 9.07 & 3.11 & 0.97 & 0.41 & \\
\hline $\mathrm{Cb}=$ basal diet & - & - & 4.36 & 0.12 & - & \\
\hline $\mathrm{Tb}=$ basal diet + RUFO & $0.80 \%$ & 18.5 & 3.87 & 0.34 & 0.22 & \\
\hline $\mathrm{C}=$ basal diet & - & ND & 3.27 & 0.30 & - & Kairenius et al., 2015 \\
\hline $\mathrm{T} 1=$ basal diet + RUFO & $75 \mathrm{~g} / \mathrm{d}$ & ND & 3.23 & 0.28 & -0.02 & \\
\hline $\mathrm{T} 2=$ basal diet + RUFO & $150 \mathrm{~g} / \mathrm{d}$ & ND & 3.14 & 0.42 & 0.12 & \\
\hline $\mathrm{T} 3=$ basal diet + RUFO & $300 \mathrm{~g} / \mathrm{d}$ & ND & 3.33 & 0.59 & 0.29 & \\
\hline $\mathrm{C}=$ basal diet & - & ND & ND & 0.30 & - & Lacasse et al., 2002 \\
\hline $\mathrm{T} 1=$ basal diet + RUFO & $3.70 \%$ & ND & ND & 1.03 & 0.73 & \\
\hline $\mathrm{T} 2=$ basal diet $+\mathrm{RPFO}$ & $1.80 \%$ & ND & ND & 0.89 & 0.59 & \\
\hline
\end{tabular}




\begin{tabular}{|c|c|c|c|c|c|c|}
\hline $\mathrm{T} 3=$ basal diet + RPFO & $3.70 \%$ & ND & ND & 1.04 & 0.74 & \\
\hline $\mathrm{C}=$ basal diet & - & - & 2.94 & 0.19 & - & Donovan et al., 2000 \\
\hline $\mathrm{T} 1=$ basal diet + RUFO & $1.00 \%$ & 14.30 & 2.77 & 0.57 & 0.38 & \\
\hline $\mathrm{T} 2=$ basal diet + RUFO & $2.00 \%$ & 50.66 & 2.35 & 1.97 & 1.78 & \\
\hline $\mathrm{T} 3=$ basal diet + RUFO & $3.00 \%$ & 92.63 & 2.28 & 1.25 & 1.06 & \\
\hline $\mathrm{C}=$ basal diet & - & ND & 3.34 & $\mathrm{ND}$ & - & Baer et al., 2001 \\
\hline $\mathrm{T}=$ basal diet + RUFO & $2.00 \%$ & ND & 2.27 & $\mathrm{ND}$ & - & \\
\hline $\mathrm{C}=$ basal diet & - & ND & 4.56 & 1 & - & Shingfield et al.,2006 \\
\hline $\mathrm{T}=$ basal diet + RUFO & $1.50 \%$ & ND & 2.87 & 0.54 & 0.54 & \\
\hline
\end{tabular}

2 Fatty acid $\approx$ triacylglycerols + diacylglycerols + monoacylglycerols + free fatty acids.

3 Milk fatty acid $=$ milk fat content $\times 99.13 \%$ (MacGibbon \& Taylor 2006).

$4 \mathrm{C}=$ control; $\mathrm{Ca}, \mathrm{b}=$ controls in article; $\mathrm{Ta}, \mathrm{b}=$ treatments in article; $\mathrm{T} 1,2,3=$ treatments.

5 RPFO: rumen protected fish oil; RUFO: rumen unprotected fish oil.

6 ND: Not detected. 


\section{Table 2 (on next page)}

The effects of dietary supplementation of microalgae on milk fat content

Fatty acid $\approx$ triacylglycerols + diacylglycerols + monoacylglycerols + free fatty acids. Milk fatty acid =milk fat content $\times 99.13 \%$ ( MacGibbon $\&$ Taylor 2006) . C=control. T1, 2, $3=$ treatments. RPA: rumen protected algae; RUA: rumen unprotected algae. ND: Not detected. 
1 Table 2. The effects of dietary supplementation of microalgae on milk fat content

\begin{tabular}{|c|c|c|c|c|c|c|}
\hline Treatment & $\begin{array}{c}\text { Microalgae } \\
\text { supplement }(\mathrm{g} / \mathrm{d})\end{array}$ & $\begin{array}{l}\text { Diet DHA } \\
\text { intake }(\mathrm{g} / \mathrm{d})\end{array}$ & $\begin{array}{l}\text { Milk fatty } \\
\text { acid }(\%)\end{array}$ & $\begin{array}{l}\text { DHA content in } \\
\text { milk } \mathrm{g} / \mathrm{d}\end{array}$ & $\begin{array}{l}\text { Increase of DHA content in } \\
\text { milk (compared with } \\
\text { control group) }(\mathrm{g} / \mathrm{d})\end{array}$ & Reference \\
\hline $\mathrm{C}=$ basal diet & - & - & 4.75 & 0.13 & - & Boeckaert et al., 2008 \\
\hline $\mathrm{T}=$ basal diet $+\mathrm{RPA}$ & 899 & 43.7 & 2.18 & 1.45 & 1.32 & \\
\hline $\mathrm{C}=$ basal diet & - & 0.05 & 3.36 & 0.70 & - & $\begin{array}{l}\text { Fougère, Delavaud \& } \\
\text { Bernard, } 2018\end{array}$ \\
\hline $\mathrm{T}=$ basal diet + RUA & 310 & 115 & 2.62 & 13.6 & 12.9 & \\
\hline $\mathrm{C}=$ basal diet & - & ND & 4.75 & 0.10 & - & Póti et al., 2015 \\
\hline $\mathrm{T}=$ basal diet + RUA & 150 & ND & 3.46 & 0.14 & 0.04 & \\
\hline $\mathrm{C}=$ basal diet & - & - & 3.67 & 0.00 & - & Franklin, et al., 1999 \\
\hline $\mathrm{T} 1=$ basal diet $+\mathrm{RPA}$ & 910 & 29.2 & 2.92 & 5.15 & 5.15 & \\
\hline $\mathrm{T} 2=$ basal diet + RUA & 910 & 35.9 & 2.92 & 3.23 & 3.23 & \\
\hline $\mathrm{C}=$ basal diet & - & - & 3.47 & 0.10 & - & Stamey et al., 2012 \\
\hline $\mathrm{T} 1=$ basal diet $+0.5 \times \mathrm{RUA}$ & 150 & 21.6 & 3.97 & 0.50 & 0.40 & \\
\hline $\mathrm{T} 2=$ basal diet $+1 \times \mathrm{RUA}$ & 300 & 43.2 & 3.27 & 0.59 & 0.49 & \\
\hline $\mathrm{T} 3=$ basal diet $+1 \times$ RUA oil & 194 & 27.4 & 3.27 & 0.30 & 0.20 & \\
\hline $\mathrm{C}=$ basal diet & - & - & 4.93 & 0.44 & - & Moate et al. 2013 \\
\hline $\mathrm{T} 1=$ basal diet + RUA & 125 & 25.0 & 3.75 & 3.51 & 3.07 & \\
\hline $\mathrm{T} 2=$ basal diet + RUA & 250 & 50.0 & 3.67 & 5.09 & 4.65 & \\
\hline $\mathrm{T} 3=$ basal diet + RUA & 375 & 75.0 & 3.80 & 7.70 & 7.26 & \\
\hline $\begin{array}{l}\mathrm{C}=\text { basal (diet }+ \text { Hydrogenated } \\
\text { palm oil fat }\end{array}$ & - & - & 3.90 & - & - & Moran et al., 2018 \\
\hline $\mathrm{T}=$ basal diet + RUA & 100 & 17.8 & 3.81 & 1.32 & 1.32 & \\
\hline
\end{tabular}

2 Fatty acid $\approx$ triacylglycerols + diacylglycerols + monoacylglycerols + free fatty acids.

3 Milk fatty acid $=$ milk fat content $\times 99.13 \%$ (MacGibbon \& Taylor 2006). 
$4 \mathrm{C}=$ control. $\mathrm{T} 1,2,3=$ treatments.

5 RPA: rumen protected algae; RUA: rumen unprotected algae.

6 ND: Not detected.

7 


\section{Table 3 (on next page)}

Efficiency of dietary incorporation of DHA into milk

DHA intake: reported in the article or calculation: dry matter intakexfatty content of diet $\times$ DHA content. Fatty acid $\approx$ triacylglycerols + diacylglycerols + monoacylglycerols + free fatty acids. Milk fatty acid =milk fat content $\times 99.13 \%$ ( MacGibbon \& Taylor 2006). Milk DHA yield: reported in the article or calculation: milk fatty yieldxDHA content. Efficiency: milk $\mathrm{DHA} / \operatorname{diet} \mathrm{DHA}$ 
1 Table 3. Efficiency of dietary incorporation of DHA into milk

\begin{tabular}{lcccl}
\hline DHA source & $\begin{array}{c}\text { DHA in } \\
\text { take }(\mathrm{g} / \mathrm{d})\end{array}$ & $\begin{array}{c}\text { Milk DHA } \\
\text { yield }(\mathrm{g} / \mathrm{d})\end{array}$ & $\begin{array}{c}\text { Efficiency } \\
(\%)\end{array}$ & \multicolumn{1}{c}{ Reference } \\
\hline Fish oil & 14.30 & 0.57 & 3.99 & Donovan et al., 2000 \\
Fish oil & 50.66 & 1.97 & 3.89 & Donovan et al., 2000 \\
Fish oil & 92.63 & 1.25 & 1.35 & Donovan et al., 2000 \\
Fish oil & 21.27 & 2.49 & 11.7 & Abughazaleh et al., 2002 \\
Fish oil & 12.20 & 1.46 & 12.0 & Abughazaleh et al., 2002 \\
Fish oil & 11.07 & 1.59 & 14.4 & Whitlock et al., 2002 \\
Fish oil & 9.07 & 0.97 & 10.7 & Whitlock et al., 2002 \\
Fish oil & 31.71 & 2.18 & 6.87 & Vafa et al., 2012 \\
Fish oil & 12.87 & 0.84 & 6.53 & Vafa et al., 2012 \\
Fish oil & 24.66 & 1.68 & 6.81 & Vahmani et al., 2013 \\
Fish oil & 17.55 & 0.40 & 2.28 & Pirondini et al., 2015 \\
Fish oil & 18.53 & 0.34 & 1.83 & Pirondini et al., 2015 \\
Microalgae & 35.94 & 3.23 & 8.99 & Franklin et al., 1999 \\
Microalgae & 43.68 & 1.45 & 3.32 & Boeckaert et al., 2009 \\
Microalgae & 25.00 & 3.51 & 14.0 & Moate et al., 2013 \\
Microalgae & 50.00 & 5.09 & 10.2 & Moate et al., 2013 \\
Microalgae & 75.00 & 7.70 & 10.3 & Moate et al., 2013 \\
Microalgae & 21.61 & 0.50 & 2.31 & Stamey et al,. 2012 \\
Microalgae & 43.23 & 0.59 & 1.36 & Stamey et al,. 2012 \\
Microalgae oil & 27.41 & 0.30 & 1.09 & Stamey et al,. 2012 \\
Microalgae & 17.82 & 1.32 & 7.41 & Moran et al,. 2017 \\
Microalgae & 115.5 & 13.6 & 11.8 & Fougère et al. 2018 \\
\hline & & & & \\
\hline$H A$ & & & &
\end{tabular}

2 DHA intake: reported in the article or calculation: dry matter intake $\times$ fatty content of $\operatorname{diet} \times \mathrm{DHA}$

3 content.

4 Fatty acid $\approx$ triacylglycerols + diacylglycerols + monoacylglycerols + free fatty acids.

5 Milk fatty acid $=$ milk fat content $\times 99.13 \%$ (MacGibbon \& Taylor 2006).

6 Milk DHA yield: reported in the article or calculation: milk fatty yield $\times$ DHA content.

7 Efficiency: milk DHA/ diet DHA. 